\title{
New Q Wave
}

National Cancer Institute

\section{Source}

National Cancer Institute. New Q Wave. NCI Thesaurus. Code C117770.

An electrocardiographic finding assessment of new or presumed new pathologic Q waves suggestive of myocardial infarction. (Thygesen $\mathrm{K}$, Alpert JS, Jaffe AS, et al.: the Writing Group on behalf of the Joint ESC/ACCF/AHA/WHF T ask Force for the Universal Definition of Myocardial Infarction. J Am Coll Cardiol 60(16):1-18, 2012). (CDISC) 